\title{
Effects of snail grazers and light on the benthic microbial food web in periphyton communities
}

\author{
Tanja Burgmer ${ }^{1}$, Julia Reiss ${ }^{1,2}$, Stephen A. Wickham ${ }^{3}$, Helmut Hillebrand ${ }^{1,4, *}$ \\ ${ }^{1}$ Erken Laboratory, Department of Limnology, Evolutionary Biology Centre, Uppsala University, Norr Malma 4200, \\ Norrtälje 761 73, Sweden \\ ${ }^{2}$ Department of Life Sciences, Roehampton University, London SW15 4JD, UK \\ ${ }^{3}$ Organismal Biology, Institute for Zoology, Hellbrunnerstr. 34, Salzburg 5020, Austria \\ ${ }^{4}$ Institute for Chemistry and Biology of the Marine Environment (ICBM), Carl-von-Ossietzky University Oldenburg, \\ Schleusenstr. 1, Wilhelmshaven 26382, Germany
}

\begin{abstract}
Periphyton harbours a complex microbial food web with different trophic levels, but little is known about trophic interactions within this food web and its response to factors that potentially control the entire community. We used natural periphyton communities from Lake Erken (Sweden) in 2 experiments manipulating grazer presence. In addition to an ungrazed control, we included natural densities of either of 2 snail species (Theodoxus fluviatilis and Bithynia tentaculata) in order to test how generalist consumers affect different components of the periphyton. In the second experiment, we additionally manipulated light supply to alter the heterotroph-autotroph ratio in the periphyton and thus potentially the trophic interactions. In both experiments, grazer presence decreased algal biomass immediately and shifted the community composition from dominance of large filamentous forms to dominance of prostrate and motile unicellular species. Biomass of bacteria, heterotrophic nanoflagellates, ciliates and meiofauna also decreased with grazing, but with differentiated temporal dynamics and effect strength. In the ungrazed control, first heterotrophic protists and later meiofaunal biomass increased, indicating strong bottom-up and top-down propagation of trophic interactions in the microbial food web. High light increased the biomass of mixotrophic ciliates and nanoautotrophs but not total algal biomass. Grazer presence decreased algal richness in the second experiment, but increased evenness of the algal community under high light conditions. We conclude that grazer presence puts different pressure on the components of the periphyton, which are further linked by direct or indirect internal trophic processes
\end{abstract}

KEY WORDS: Periphyton $\cdot$ Microbial food web $\cdot$ Protozoa $\cdot$ Algae $\cdot$ Grazer $\cdot$ Light

\section{INTRODUCTION}

In pelagic systems, the microbial food web is recognised as an important factor increasing the efficiency of production of the whole planktonic food web (Azam et al. 1983). Heterotrophic nanoflagellates and ciliates as major grazers on bacteria can transform microbial production into larger particles that are available for macroconsumers and thus returns organic matter originating from phytoplankton exudates, faecal material, dissolved and particulate material to the classic food web. This function is important because the components of the microbial food web have the potential for rapid growth and efficient conversion of food into biomass (Porter et al. 1985). Many zooplankton species are predators on protozoans and can alter protist abundance and composition directly or indirectly by reducing grazing pressure through feeding on other zooplankton (Arndt 1993, Sanders \& Wickham 1993, Jürgens et al. 1999).

In sediments, the role of microbial food webs has also been investigated by addressing trophic interactions 
between bacteria, protozoa and meiofauna. Such interactions often have both direct and indirect consequences. Ciliates can affect bacteria directly through moderate grazing, but also indirectly through grazing on bacterivorous heterotrophic nanoflagellates (Fenchel 1982, McManus \& Fuhrman 1986). Ciliates also graze on diatoms, although they appear to be unable to control overall algal abundance (Epstein et al. 1992). Similarly, ciliates themselves have been observed to be influenced by benthic meiofauna (Epstein \& Gallagher 1992). Meiofauna feed on benthic bacteria and protists in experiments using freshwater or marine organisms (Rieper 1985, Bott \& Borchardt 1999, Hamels et al. 2001, Wieltschnig et al. 2003).

Although the main groups of the microbial food web and their potential predators can also be found in periphyton, the role of these heterotrophs in the assemblages is less well understood. Periphyton is a complex, spatially compact assemblage covering all kinds of hard substrates in aquatic ecosystems and comprising different trophic levels. In euphotic zones of lakes, streams and coastal areas, algae dominate the assemblage, but are closely linked to heterotrophs such as bacteria, protozoa and small metazoa. In an extensive laboratory study, Fitter \& Hillebrand (2009) showed that the trophic structure of the microbial food web strongly affected the functional composition of the entire assemblage and the propagation of resources such as nutrients, light, and organic carbon. The stoichiometry of elemental content in the entire periphyton responded significantly to the presence and absence of certain components of the microbial food web such as meiofauna.

Periphyton biomass and architecture tends to be strongly affected by grazing from insect larvae, crustaceans or snails (Feminella \& Hawkins 1995, Steinman 1996, Hillebrand 2009). These consumers are large compared to their prey, such that they ingest parts of the entire assemblage and leave macroscopically visible grazing tracks. The large consumer:prey ratio suggests an unselective grazing pressure on all components of the periphyton community, but so far, almost all studies on grazer-periphyton interactions focused on the algal component of periphyton. Some studies focused on the response of certain heterotrophic groups to grazing, e.g. bacteria (Lamberti and Resh 1983, Mulholland et al. 1991, Morales \& Ward 2000) or meiofauna (Bell 1980, Schmid-Araya \& Schmid 2000, Peters et al. 2007). Very few studies investigated the simultaneous effect of grazing on autotrophic and multiple heterotrophic components.

In multiple field experiments, Hillebrand et al. (2002) reported differential impact of grazers on algae, ciliates, bacteria and meiofauna, with algal biomass reduced but some heterotrophs favored by grazer presence. Further detailing these analyses, Wickham et al. (2004) showed that grazer presence increased ciliate biomass but did not affect ciliate diversity, whereas the bacterial response to grazer presence depended on nutrient conditions (Haglund \& Hillebrand 2005). This field study indicated that grazing pressure can have highly diverging effects on autotrophic and heterotrophic components of the periphyton, but the mechanism underlying these differences remained elusive, which was mainly due to the lack of data on temporal dynamics of the different groups as only final yield was measured.

In this study, we combined the use of structurally complex natural periphyton assemblages with controlled laboratory settings in order to address the temporal dynamics of grazing effects on algae, heterotrophic flagellates, ciliates, and meiofauna. We conducted 2 experiments: the first detailing effects of 2 snail species on all components; the second cross-classifying grazer presence with reduced light supply, which was supposed to alter the heterotroph:autotroph ratio in the assemblage. We tested the following hypotheses: (1) Heterotrophic components of the periphyton show a different magnitude and temporal sequence of response to grazer presence compared to autotrophs. (2) The responses differ for 2 snail species with known differences in grazing efficiency. (3) The reduction in light results in a more heterotrophic assemblage that consequently alters grazing effects on community composition.

\section{MATERIALS AND METHODS}

Experimental design. For colonization with natural periphyton communities, unglazed ceramic tiles $(2.5 \times$ $2.5 \mathrm{~cm}$ ) were exposed for 3 mo in Lake Erken in Sweden $\left(59^{\circ} 25^{\prime} \mathrm{N}, 18^{\circ} 15^{\prime} \mathrm{E}\right)$.

Two snail species common in Lake Erken were chosen as model organisms for different grazer types. Theodoxus fluviatilis can be characterized by high mobility and high grazing efficiency (Stendera 2000), whereas Bithynia tentaculata was observed to be less mobile and to graze in a more heterogeneous way (Brendelberger \& Jürgens 1993). B. tentaculata is also able to switch to filter feeding if enough food is suspended, and it stays inactive if high quality food is not available (Brendelberger 1997). Whereas both snails are similar in size $(\geq 10 \mathrm{~mm})$ and can be regarded as generalist consumers of the entire assemblage, we expected $T$. fluviatilis to produce a stronger and more uniform grazing pressure than B. tentaculata.

At the onset of the experiment, the pre-grown ceramic tiles covered with dense periphyton were - after visible macrozoobenthos had been carefully removed with 
forceps - brought to a temperature-controlled room where they were allowed to adapt to experimental conditions for $1 \mathrm{wk}$. The snails were sampled from Lake Erken together with the periphyton and also adapted to experimental conditions. The temperature was held constant at $16.2^{\circ} \mathrm{C}$ and light was provided from above by Osram Biolux and Fluora lamps in a $12 \mathrm{~h}$ light:12 h dark rhythm (for intensities see 'Expt 1' and 'Expt 2'). Aquaria were aerated with aquarium pumps.

Expt 1: The first experiment ran for 23 d from 22 April to 15 May 2002. Three treatments with 4 replicates each were randomly assigned to 12 plastic aquaria (bottom area: $425 \mathrm{~cm}^{2}$ ) filled with $3.1 \mathrm{l}$ filtered (GF/F filter) lake water, and with 36 of the pre-grown ceramic tiles (combined tile area: $225 \mathrm{~cm}^{2}$ ) placed in each. Then, 10 to 13 individuals of Bithynia tentaculata (mean blotted fresh weight per aquarium $\pm \mathrm{SE}=1.84 \pm$ $0.01 \mathrm{~g}$ ) were added to Bithynia treatments (BIT). Theodoxus treatments (THE) were stocked with 9 to 13 individuals of Theodoxus fluviatilis (mean blotted fresh weight per aquarium $=1.26 \pm 0.05 \mathrm{~g}$ ). This was in accordance with natural snail densities of both species $\left(\sim 250 \mathrm{~m}^{-2}\right)$ observed in Lake Erken (Hillebrand \& Kahlert 2001). As controls (CON), 4 aquaria with 36 tiles each were used and kept without snails. Photon flux density was $58 \mu \mathrm{mol}$ photons $\mathrm{m}^{-2} \mathrm{~s}^{-1}$. Dead snails were replaced by individuals of similar weight and size, which was necessary only 3 times $(2 \mathrm{~B}$. tentaculata, 1 T. fluviatilis).

Expt 2: The second experiment ran for $15 \mathrm{~d}$ from 13 to 28 June 2002. The 3 grazer treatments (CON, BIT, THE) were randomly assigned to 24 plastic aquaria (bottom area: $64 \mathrm{~cm}^{2}$ ). Of these aquaria, 12 were used for high light (HL) treatments, representing saturating light intensities with photon flux densities of $251 \mu \mathrm{mol}$ $\mathrm{m}^{-2} \mathrm{~s}^{-1}$, the other 12 for low light (LL) treatments, representing limited light conditions with photon flux densities of $<5 \mu \mathrm{mol} \mathrm{m} \mathrm{m}^{-2} \mathrm{~s}^{-1}$. Each light $\times$ grazing combination was replicated 4 -fold. The large difference between HL and LL spans the full range of light conditions naturally experienced by periphyton from clearly saturating (near photoinhibition) to highly limiting (near compensation) light supply (Hill 1996). We chose this large gradient in order to produce strongly autotrophic and heterotrophic growth conditions. Nine tiles (combined tile area: $56 \mathrm{~cm}^{2}$ ) were placed in each of the 24 aquaria, filled with $200 \mathrm{ml}$ filtered (GF/F filter) lake water. According to the smaller aquarium size and combined tile area, BIT treatments were stocked with 2 individuals of Bithynia tentaculata (mean blotted fresh weight per aquarium $=0.38 \pm 0.01 \mathrm{~g}$ ) and THE treatments with 2 individuals of Theodoxus fluviatilis (mean blotted fresh weight per aquarium $=0.47 \pm$ $0.01 \mathrm{~g})$. Thus, snail densities $\left(312 \mathrm{~m}^{-2}\right)$ reached roughly the same level as in Expt 1. With 4 at HL and 4 at LL,
8 aquaria were kept as CON without snails. During the experiment, just 1 dead individual (B. tentaculata) had to be replaced by an individual of similar size and weight.

Sampling. Sampling took place at Days 0, 2, 4, 8, 15 and 23 for Expt 1. Every sampling day, 3 randomly determined tiles were taken out of each aquarium and placed in petri dishes. Removed tiles were replaced by new ones with pre-grown periphyton to reduce artefacts of grazing on reduced area. The same position was never sampled twice, i.e. all sampled tiles were in the aquaria from the start of the experiment. The periphyton was carefully scraped off by a scalpel and carefully separated by scissors and forceps. The biomass was suspended in filtered lake water, filled up to $50 \mathrm{ml}$ and subdivided in subsamples for each group of organisms (see 'Fixation, counting and calculation').

Sampling procedure was nearly the same for Expt 2 except it was done only at 3 dates (Days 0, 4 and 15). The first results of Expt 1 indicated that these days were decisive for the development, and thus the sampling effort could be reduced. For Day 0, eight replicates (with 3 tiles each) were sampled out of the common tile pool and taken as start values for all treatments.

Fixation, counting and calculation. Microalgae: The subsamples $(5 \mathrm{ml})$ for microalgae were fixed with Lugol's iodine. Enumeration of microalgae was done using $3 \mathrm{ml}$ Utermöhl chambers under an inverted microscope at $400 \times$ magnification, and at least 400 cells were counted per sample (Utermöhl 1958). Species not identifiable in preserved samples were put into groups, which were used consistently throughout the experiments. Biovolume for each species or group was calculated with best fitting geometric models and measurements of linear dimensions under the microscope (Hillebrand et al. 1999). Microalgal carbon was calculated from biovolume using the equation given by Menden-Deuer \& Lessard (2000). Microalgal diversity was determined as species richness $(S)$ and as Pielou's evenness $(J)$ using biovolume proportions (Hillebrand \& Sommer 2000), where $J$ is based on the Shannon diversity index: $J=H^{\prime} / \ln S$. Additionally, we classified algae into growth forms in order to address changes in community architecture with grazing and light treatments (Steinman 1996, Hillebrand 2003). We distinguished filamentous forms (including filaments, but also chain-forming diatoms), prostrate forms (tightly attached diatoms such as Cocconeis sp., but also crustose algae), stalked species (such as Gomphonema or Cymbella), motile unicellular species, and a category 'other' including araphid sessile diatoms and planktonic Centrales.

Bacteria and flagellates: One subsample of $5 \mathrm{ml}$ was preserved with glutaraldehyde (final concentration 
$2 \%$ ) for bacterial and flagellate enumeration with epifluorescence microscopy. For bacterial counting, $1 \mathrm{ml}$ of the suspension was diluted 10 times with $0.2 \mu \mathrm{m}$ filtered lake water. Sonication (1 min at $20 \mathrm{~W}$ ) and subsequent re-dilution (final dilution, density dependent, $200,100,80,40$, or 10 times) was used to break up bacterial clumps, a method that had previously been used successfully in the same system (Hillebrand et al. 2002). The samples were then DAPI-stained, filtered onto black polycarbonate filters $(0.2 \mu \mathrm{m}$ pore size), and a minimum of 400 cells counted at $1250 \times$ magnification. To evaluate the mean cell volume, linear dimensions of more than 100 cells were measured and cell volumes were calculated with geometric formulas (sphere for cocci, cylinder with 2 half-spheres at each end for rods). From bacterial abundance and mean cell volume (CV), bacterial biomass was calculated as carbon content (CC) using the allometric conversion factor: $\mathrm{CC}=218 \mathrm{CV}^{0.86}$ (Loferer-Krößbacher et al. 1998).

To count flagellates, the rest of the subsample was vigorously shaken for $30 \mathrm{sec}$ to separate the flagellates from the clumps. The protocol for bacteria was used with different dilution (final dilution, density dependent, 80, 40, or 10 times) and black polycarbonate filter (0.8 $\mu \mathrm{m}$ pore size). Flagellates were counted under UV light to enumerate total flagellate abundance and under blue light to enumerate autotrophic flagellates only, thus quantifying both heterotrophic (HNAN) and photoautotrophic nanoflagellates (PNAN). As PNAN were too small to be counted with the Utermöhl method $(<5 \mu \mathrm{m})$, PNAN have not been confounded with the microalgae counted with the Utermöhl technique and have thus been considered as a specific component of phototrophic eukaryotes. At least 40 heterotrophs and 40 autotrophs were counted and measured per slide. When this was not possible, at least $150 \times 125 \mu \mathrm{m}$ of the filter was counted. For biomass calculations, species-specific biovolume was calculated with the geometric formulas for spheres and ellipses and converted to $\mathrm{CC}$ using the conversion fac-

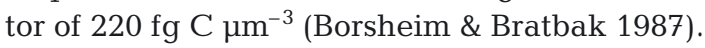

Ciliates: Ciliates were fixed with Bouin's fixative ( $5 \%$ final concentration of a $10 \mathrm{ml}$ subsample) and counted in Utermöhl chambers with an inverted microscope (Zeiss Axiovert S 100). Because of dense periphyton, many treatments had to be diluted (by a factor of 2 to 7 ). A second chamber was counted if less than 4 individuals were found in the first one. Each ciliate was measured and assigned to morphological groups using QPS (quantitative protargol stain) filters following Skibbe (1994) with minor modifications. If possible, ciliates were determined to species level, but often differentiation in the samples was only possible to genus or even order level. Therefore, 6 taxonomical groups were differentiated consistently: Litostomatea (e.g.
Lacrymaria sp.; Dileptus sp.); Hypotrichia (Euplotes sp.; Aspidisca sp.) and Stichotrichia (Stylonychia mytilus; Phyllopharyngia [e.g. Chilodonella uncinata]); Oligohymenophorea (comprising small hymenostoms such as Paramecium bursarium and scuticociliates with small Cyclidium-sized forms and the genus Pleuronema); and Peritrichia (excluded from Oligohymenophorea with e.g. Vorticella sp., Cothurnia sp. and non-sessile species of the order Mobilida). The last group, named 'Others', included some species of the order Heterotrichida, some oligotrichs and not identified species.

Biomass was calculated with the biovolume: $\mathrm{CC}$ ratio for formalin-preserved cells by Putt \& Stoecker (1989), which also fits for Bouin's-preserved cells. Biovolume calculations were made with geometric formulas of the most appropriate geometric forms.

Meiofauna: Two subsamples were used for the investigation of meiofauna. A subsample of $5 \mathrm{ml}$ was scanned for living meiofauna in order to register fragile taxa. Another subsample $(20 \mathrm{ml})$ was decanted over a $40 \mu \mathrm{m}$ sieve and the retained fauna was fixed with hot $\left(40^{\circ} \mathrm{C}\right)$ formalin-acetic acid-alcohol (FAA) $(20$ parts of $95 \%$ ethanol, 6 parts of $38 \%$ formalin, 1 part of glacial acid, 40 parts of distilled water; Traunspurger 1997). Identification and enumeration of meiofauna was performed under an Olympus stereomicroscope at $40 \times$ magnification, after the sample had been stained with Rose Bengal (Fluka, 1\%). For biomass calculations, all individuals were measured for each treatment. Exceptions were made for the numerous nematodes, rotifers and oligochaetes, whose mean size was estimated from measuring 100 individuals in $\mathrm{CON}$ treatments of Days 0 and 23, respectively. Speciesspecific biovolume was calculated using the equations published by Feller \& Warwick (1988) and by assuming an ellipsoid body shape in the case of rotifers. Organism volume was converted to individual fresh weight assuming a specific gravity of 1.1 for rotifers and 1.13 for the other groups (Feller \& Warwick 1988). The fresh weight of nematodes and chironomids was obtained from published equations (Andrassy 1956, Balushkina 1982). The individual $C C$ was estimated assuming a dry:wet wt ratio of 0.25 and a dry wt CC of $40 \%$ (Feller \& Warwick 1988).

Statistical analysis. For biomass of all investigated groups as well as algal species richness and evenness, repeated-measures analysis of variance (rmANOVA) was used to detect significant effects of treatments and significant changes over time within treatments. In Expt 1, grazing (CON, BIT, THE) represented the factor between subjects, whereas time (Days 0, 2, 4, 8, 15, 23 ) and time $\times$ grazing were analysed within subjects. In Expt 2, a factorial $3 \times 2$ combination of grazing (CON, BIT, THE) and light treatments (HL, LL) was 
used between subjects, whereas time as well as all interactions involving time (Days 4 and 15) were analysed within subjects. Effects were considered significant if $\mathrm{p}<0.05$ and highly significant if $\mathrm{p}<0.001$. The analyses were done on separately obtained data for the different groups of organisms. Thus, although these organism groups interact and affect each others' biomass, the analysis of their response to treatments is independent for each single group. In cases where the hypotheses can be tested independently, no adjustment of significance level is necessary. To homogenize the variances, log-transformed data were used for all statistical analyses involving biomass, whereas algal richness and evenness showed homogeneous variances without transformation (please note that graphical displays use arithmetic means and SE). As post hoc test, Tukey's honestly significant difference (HSD) was chosen to compare treatment levels (CON, BIT, THE). In cases of significant time $\times$ treatment interactions, a separate ANOVA was performed for each sampling day to elucidate the temporal sequence of significant treatment effects.

Multivariate analysis of variance (MANOVA) was used to test for significant impacts of treatments on ciliate and algal community composition, respectively. The proportions of algal growth forms or ciliate taxonomic units on the final day of the experiment (23 or 15 , respectively) were tested in a 1-factor MANOVA for grazing (Expt 1) or a 2-factor MANOVA for grazing and light (Expt 2). For algae, the proportions of the 5 growth forms were used as dependent variables. For ciliates, we had to collapse all but 2 groups into a large category 'Other' due to the high number of absences. For both MANOVAs, Pillai's Trace statistic was used, which is a recommended test statistic for the test of interdependent response variables (Scheiner 1993). In case of significant effects, we performed subsequent univariate tests to identify groups responding significantly to treatment levels. All statistical tests were made using Statistica 6.0 (Statsoft).

For comparison, we calculated also the contribution of the different organism groups to total periphyton biomass, which represents the sum of all measured components, but excludes detritus or other organic or anorganic material.

\section{RESULTS \\ Expt 1}

At the start of the experiment, the periphyton composition was dominated by microalgae (mostly diatoms) and nanoautotrophs (PNAN) with 65 and $15 \%$ of total periphyton biomass, respectively. Biomasses of meiofauna $(11 \%)$, bacteria $(8 \%)$ and ciliates $(1 \%)$ were lower, while heterotrophic nanoflagellates (HNAN) were found in proportions of $<1 \%$ of the total biomass.

Both snail species had a strong grazing impact on microalgae. While algal biomass decreased immediately in BIT and THE treatments, it initially increased in CON up to Day 4, but then declined to the end of the experiment (Fig. 1A). Presence of either grazer reduced algal biomass significantly (Table 1), with Theodoxus fluviatilis producing significantly stronger effects than Bithynia tentaculata (Tukey's HSD, CON > BIT $>$ THE). Time $\times$ grazing interactions were significant (Table 1), indicating an increasing grazing effect that was significant from Day 4 onwards (Fig. 1A). At the end of the experiment, T. fluviatilis reduced algal biomass to $6.4 \%$ and B. tentaculata to $18.5 \%$ of the ungrazed control.

Table 1. F-ratios from repeated-measures ANOVA on Expts 1 and 2. For each experiment, treatment effects between subjects (grazing and grazing $\times$ light in Expts $1 \& 2$, respectively) and temporal trends within subjects (time and time $\times$ treatment interactions) are analysed for log-transformed biomass (algae, phototrophic [PNAN] and heterotrophic [HNAN] nanoflagellates, bacteria, ciliates and meiofauna) and algal diversity (evenness $[J]$, species richness $[S]$ ). Corresponding df are given. Significant F-ratios: ${ }^{* * *} \mathrm{p}<0.001,{ }^{* *} \mathrm{p}<0.01,{ }^{*} \mathrm{p}<0.05,\left({ }^{*}\right), \mathrm{p}<0.1$

\begin{tabular}{|lccccccccc}
\hline Factor & df & Algae & PNAN & Bacteria & HNAN & Ciliates & Meiofauna & $J$ \\
\hline Expt 1 & & & & & & & & \\
Grazing & $2 ; 9$ & $47.05^{* * *}$ & $11.93^{* *}$ & $253.54^{* * *}$ & $4.00\left(^{*}\right)$ & $12.48^{* *}$ & $18.77^{* * *}$ & 0.77 & 0.63 \\
Time & $5 ; 4$ & $48.22^{* * *}$ & $40.54^{* * *}$ & $78.28^{* * *}$ & $5.38^{* * *}$ & $36.32^{* * *}$ & $3.49^{* *}$ & 1.00 & $3.89^{* *}$ \\
Time $\times$ grazing & $10 ; 45$ & $10.48^{* * *}$ & $10.61^{* * *}$ & $22.71^{* * *}$ & $3.10^{* *}$ & $1.81\left({ }^{*}\right)$ & $16.01^{* * *}$ & 0.59 & 0.90 \\
Expt 2 & & & & & & & & \\
Light & $1 ; 18$ & 1.26 & $12.31^{* *}$ & $5.31^{*}$ & 0.00 & $6.25^{*}$ & $3.93\left(^{*}\right)$ & 0.29 & 0.31 \\
Grazing & $2 ; 18$ & $130.97^{* * *}$ & $14.52^{* * *}$ & $35.24^{* * *}$ & $5.80^{*}$ & $4.52^{*}$ & $18.41^{* * *}$ & $9.30^{* *}$ & $9.71^{* *}$ \\
Light $\times$ grazing & $2 ; 18$ & 1.73 & 1.46 & 1.00 & 1.05 & $<0.01$ & 0.04 & $5.08^{* *}$ & 1.73 \\
Time & $1 ; 18$ & 0.69 & $32.86^{* * *}$ & $41.89^{* * *}$ & $4.02\left(^{*}\right)$ & $10.77^{* *}$ & $39.54^{* * *}$ & 0.13 & 1.36 \\
Time $\times$ light & $1 ; 18$ & 0.18 & $4.98^{*}$ & $3.25\left(^{*}\right)$ & 1.31 & $5.44^{*}$ & 0.42 & 1.69 & 0.01 \\
Time $\times$ grazing & $2 ; 18$ & 0.25 & 0.10 & 2.40 & 0.57 & 1.47 & $4.99^{*}$ & 0.22 & 1.76 \\
Time $\times$ light $\times$ grazing & $2 ; 18$ & 0.63 & 1.15 & 0.49 & 1.93 & 0.06 & 0.08 & 0.58 & 0.18 \\
\hline
\end{tabular}



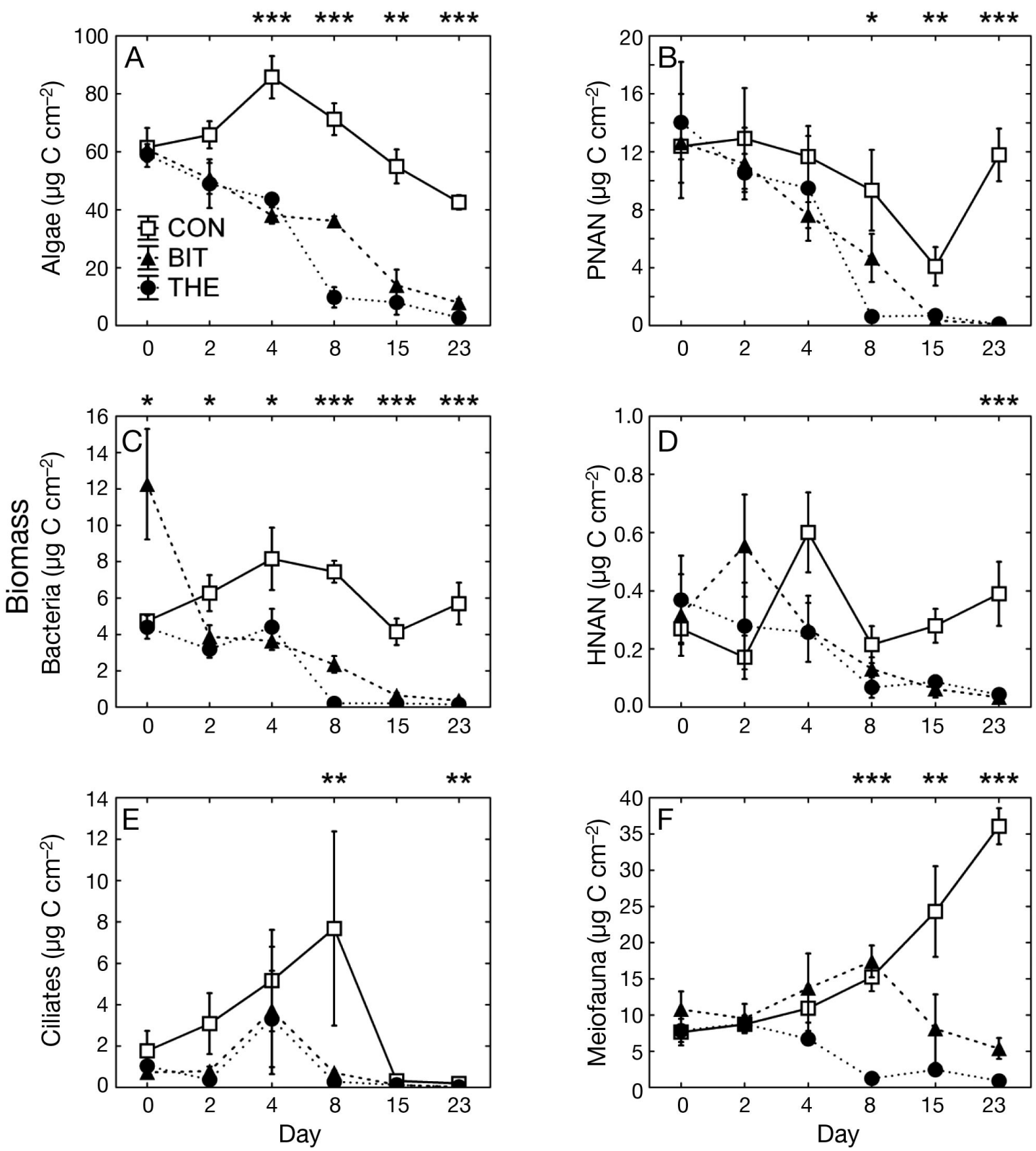

Fig. 1. Biomass development over time of different functional groups in Expt 1. All biomasses were converted to carbon units, but note different scales for the different panels. Error bars: \pm 1 SE of mean. (A) Algae. (B) Phototrophic nanoflagellates (PNAN). (C) Bacteria. (D) Heterotrophic nanoflagellates (HNAN). (E) Ciliates. (F) Meiofauna. Treatments: control (CON), Bithynia tentaculata (BIT), Theodoxus fluviatilis (THE). For factors with significant overall grazing $\times$ time interactions (repeated-measures ANOVA, see Table 1), the significant treatment effects on single sampling days are highlighted above each panel. ${ }^{* * *} \mathrm{p}<0.001$,

${ }^{* *} p<0.01,{ }^{*} p<0.05$

Microalgal composition in CON remained rather stable throughout the experiment, with a dominance of large motile diatoms and filaments, whereas significant changes could be observed in the grazed treatments (MANOVA, Pillai's Trace $=1.34, F_{8 ; 14}=3.58, \mathrm{p}=$ 0.018). Filamentous species were significantly reduced by both grazers (CON > BIT $=$ THE). The presence of Theodoxus fluviatilis increased the proportion of motile diatoms, whereas the presence of Bithynia ten- taculata increased the proportion of prostrate species (Fig. 2A). The strong effect of grazing on algal species composition was not reflected in algal diversity, neither for species richness (Fig. 2B) nor for evenness (Fig. 2C). Only a weak trend of richness over time was significant (Table 1).

PNAN, consisting of autotrophic flagellates and small non-motile algae (mostly about $5 \mu \mathrm{m}$ ), showed a similar trend as microalgae with immediate decline of 

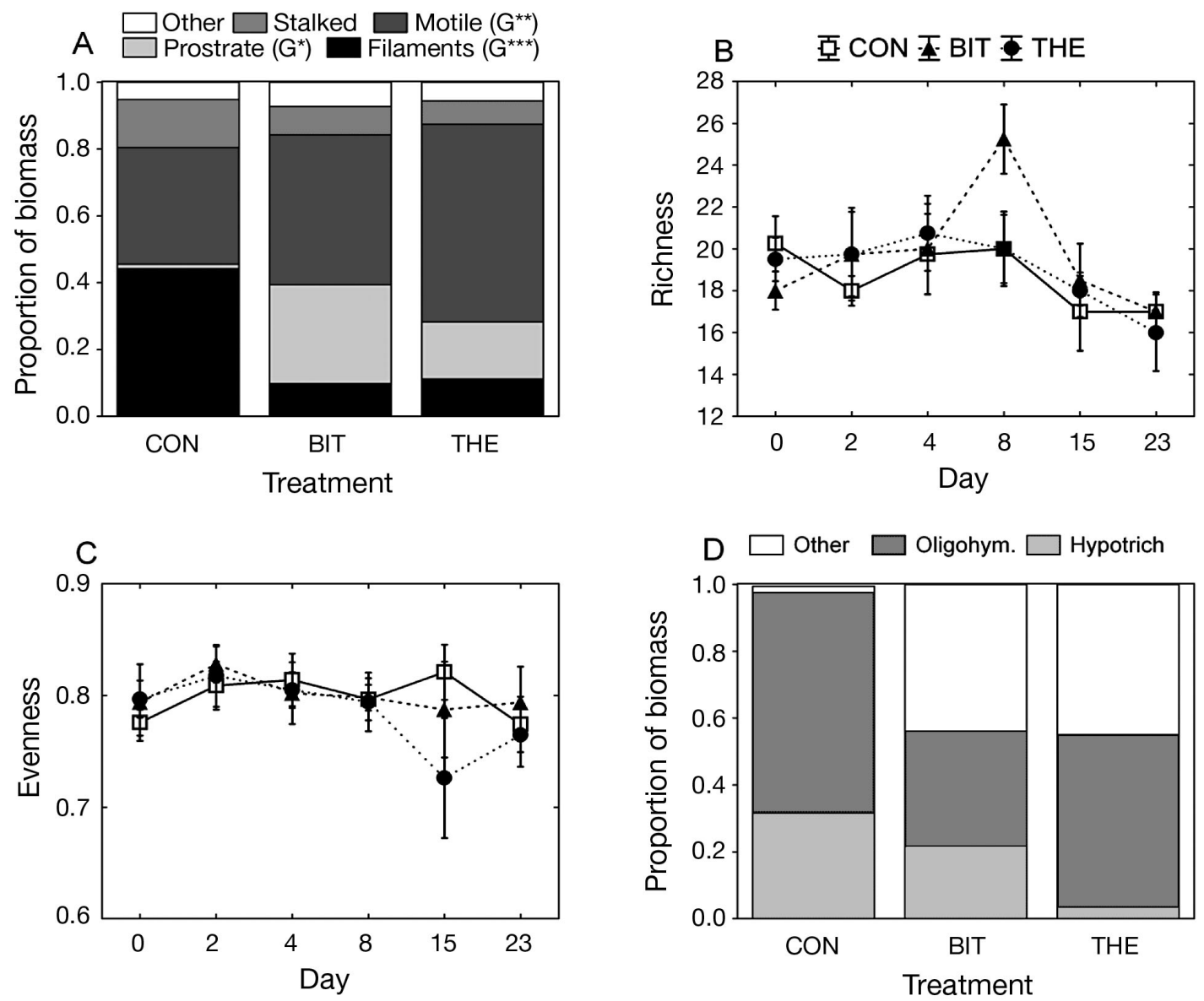

Fig. 2. Species composition and diversity for (A-C) algae and (D) ciliates in Expt 1. Error bars: \pm 1 SE of mean. (A) Final biomass proportion for different growth forms of microalgae. For treatments with significant overall effects on group composition (MANOVA), the significant grazing effects (G) on single algal groups are indicated in the key. ${ }^{* * *} \mathrm{p}<0.001,{ }^{* *} \mathrm{p}<0.01,{ }^{*} \mathrm{p}<0.05$. (B) Species richness and (C) evenness of algae. (D) Final biomass proportion for 3 ciliates groups (Oligohymenophorea [Oligohym.], Hypotrichia and Stichotrichia [Hypotrich], Other). Treatments: see Fig. 1 for definitions

PNAN biomass in the snail treatments and a decrease in $\mathrm{CON}$ at the end of the experiment (Fig. 1B). Both grazers reduced PNAN biomass significantly (Table 1 $\mathrm{CON}>\mathrm{THE}=\mathrm{BIT}$ ) and the significant time $\times$ grazing interaction reflected that grazer effects became significant from Day 8 onwards. At Day 23, PNAN biomass in both snail treatments was reduced to $<1 \%$ of the control biomass (BIT: 0.8\%, THE: 0.9\%).

Higher bacterial biomass was observed on the starting day in BIT, which was the only significant difference between treatments at Day 0 for any response variable (Fig. 1C). From Day 2 onwards, bacterial biomass was significantly higher in CON than in both grazer treatments (Table 1). Whereas bacterial biomass first increased and then decreased in CON, it decreased immediately in both BIT and THE. Grazer effects were significant from Day 2 onwards (Fig. 1C), resulting in a very low bacterial biomass at the end of the experiment in THE (2.4\% of control) and BIT $(6.4 \%$ of control) (CON > BIT > THE).
Overall, HNAN biomass was low compared to other groups (Fig. 1D). In BIT and CON, the biomass of HNAN showed an initial peak, whereas it consistently declined in THE. The overall grazer effect was marginally non-significant (Table 1 ), but a time $\times$ grazing interaction reflected that snail presence reduced HNAN biomass significantly only on Day 23 (Fig. 1D), albeit a trend was already detected on Day 15. At the end, grazed HNAN biomass was $8.6 \%$ (BIT) to $11.1 \%$ (THE) of the ungrazed control, and only BIT and CON differed significantly (Tukey's HSD).

Grazing had a significant negative effect on ciliate biomass (Table 1); however, the effect was less persistent (significant only for Days 8 and 23) and weaker compared to the other protists. An initial increase in all treatments, especially in CON, abruptly ended in a strong biomass decline after Day 4 (BIT and THE) or 8 (CON; Fig. 1E). Both snails reduced ciliate biomass to 9.0 (BIT) and $13.0 \%$ (THE) of the control biomass, respectively $(\mathrm{CON}>\mathrm{BIT}=\mathrm{THE})$. 
Final composition of the ciliates was not significantly affected by grazing (MANOVA, Pillai's Trace $=0.34$, $F_{4 ; 16}=0.81, \mathrm{p}=0.539$ ), although the most abundant groups, Oligohymenophorea and hypo- and stichotrich ciliates, showed a dramatic reduction in relative biomass (Fig. 2D). However, variation between replicates was high, rendering the highly overproportional reduction in hypo- and stichotrich biomass $(0.7$ and $1.8 \%$ compared to CON left in BIT and THE, respectively) non-significant.

Meiofaunal biomass was largely dominated by nematodes contributing on average $86 \%$ to the total meiofaunal biomass, followed by copepods and chironomids. Although meiofaunal biomass in the grazer treatments, especially THE, was finally reduced (Fig. 2F), meiofauna dynamics differed from all other groups. In CON, a 4 - to 5 -fold increase of biomass could be observed during the experiment. Even in BIT treatments, meiofaunal biomass showed an increase parallel to CON until Day 8 and never reached the low biomass of THE. Nevertheless, the grazing effect and the time $\times$ grazing interactions were significant (Table 1). Post-hoc tests revealed a significant difference between THE and CON, but not between CON and BIT. A significant grazer $\times$ time interaction indicated that grazer effects became evident only from Day 8 onwards. At the end of the experiment, meiofaunal biomass was $2.5 \%$ of the control in THE and $14.9 \%$ in BIT.

\section{Expt 2}

Periphyton biomass and composition differed between experiments. Overall, biomass at the start of Expt 2 was roughly $50 \%$ of that found in Expt 1 . The starting biomasses of PNAN and HNAN were orders of magnitude lower in Expt 2 than in Expt 1 (cf. Figs. 3 \& 1). Microalgae contributed $43 \%$ to the overall periphyton biomass, which was further dominated by meiofauna (39\%) and bacteria (17\%). Ciliates contributed $1.3 \%$ and both nanoflagellate groups contributed $<1 \%$.

Microalgal biomass remained constant in $\mathrm{CON}$, but decreased dramatically in BIT and THE $(\mathrm{CON}>\mathrm{BIT}=$ THE) (Fig. 3A). The highly significant grazer effect (Table 1) reduced algal biomass finally to 11.8 (BIT) and $8.3 \%$ (THE) of control biomass in LL, but only to 20.3 (BIT) and $17.9 \%$ (THE) in HL, respectively. Light had no significant effect on microalgal biomass, and no significant variation between sampling dates was detected.

Significant grazing and light effects on the composition of the microalgal community were found at the end of the experiment (MANOVA, grazing: Pillai's
Trace $=0.79, F_{8 ; 32}=2.62, \mathrm{p}=0.025 ;$ light: Pillai's Trace $\left.=0.46, F_{4 ; 15}=3.15, \mathrm{p}=0.046\right)$. The presence of either grazers reduced the proportional biomass of filaments (Fig. 4A; CON > THE = BIT). Theodoxus fluviatilis significantly increased the proportion of motile diatoms (THE $>$ CON = BIT). Low light conditions significantly reduced the proportion of filaments and the 'Other' algae group (Fig. 4A), but increased the proportion of stalked diatoms.

The strong reduction in microalgal biomass and the significant change in composition resulted in significant reduction of species richness by both grazers (Table 1, Fig. 4B). This reduction was more pronounced early in the experiment (Day 4), but the time $\times$ grazing interaction was not significant. For the evenness of the algal community, a significant interaction between light and grazing (Table 1) reflected the increase of evenness with grazing at HL conditions, whereas no grazing effect was observed under LL conditions (Fig. 4C). Both grazers maintained evenness at high levels (BIT $=$ THE $>$ CON).

Although PNAN were present only in very low biomass, they were significantly reduced by the grazers (Table 1, Fig. 3B). Comparably to the microalgae, PNAN biomass was reduced to $23.9 \%$ of ungrazed CON biomass across grazer treatments, and no significant difference between BIT and THE was detected (Tukey's HSD). In contrast to microalgae, PNAN biomass increased significantly with HL availability, an effect detected only at the end of the experiment (significant time $\times$ light interaction, Table 1).

Bacterial biomass decreased in all treatments with time (Fig. 3C). The bacterial biomass in the control was always higher than biomass in snail treatments (Table 1). Theodoxus fluviatilis reduced bacterial biomass significantly more (to $31.1 \%$ of CON in HL and $16.6 \%$ in LL) than Bithynia tentaculata (51.5 and $49.3 \%$ in HL and LL, respectively). A significant light effect and a marginally non-significant time $\times$ light interaction (Table 1) reflected that bacterial biomass was higher in HL than in LL at the end of the experiment.

Bithynia tentaculata had a significant negative effect on the HNAN biomass (Table 1, Fig. 3D), whereas HNAN biomass in THE was not significantly different from CON or BIT (Tukey's HSD). HNAN biomass decreased in BIT to $55.0 \%$ of CON, in THE even to $51.7 \%$, but with much higher variability through time and between replicates (Fig. 3D). Starting out with very low biomasses, HNAN increased slightly over time in CON. There was no significant light effect and no treatment $\times$ time interaction (Table 1 ).

Ciliate biomass decreased over time in all treatments (Fig. 3E). Ciliate biomass was significantly reduced by 

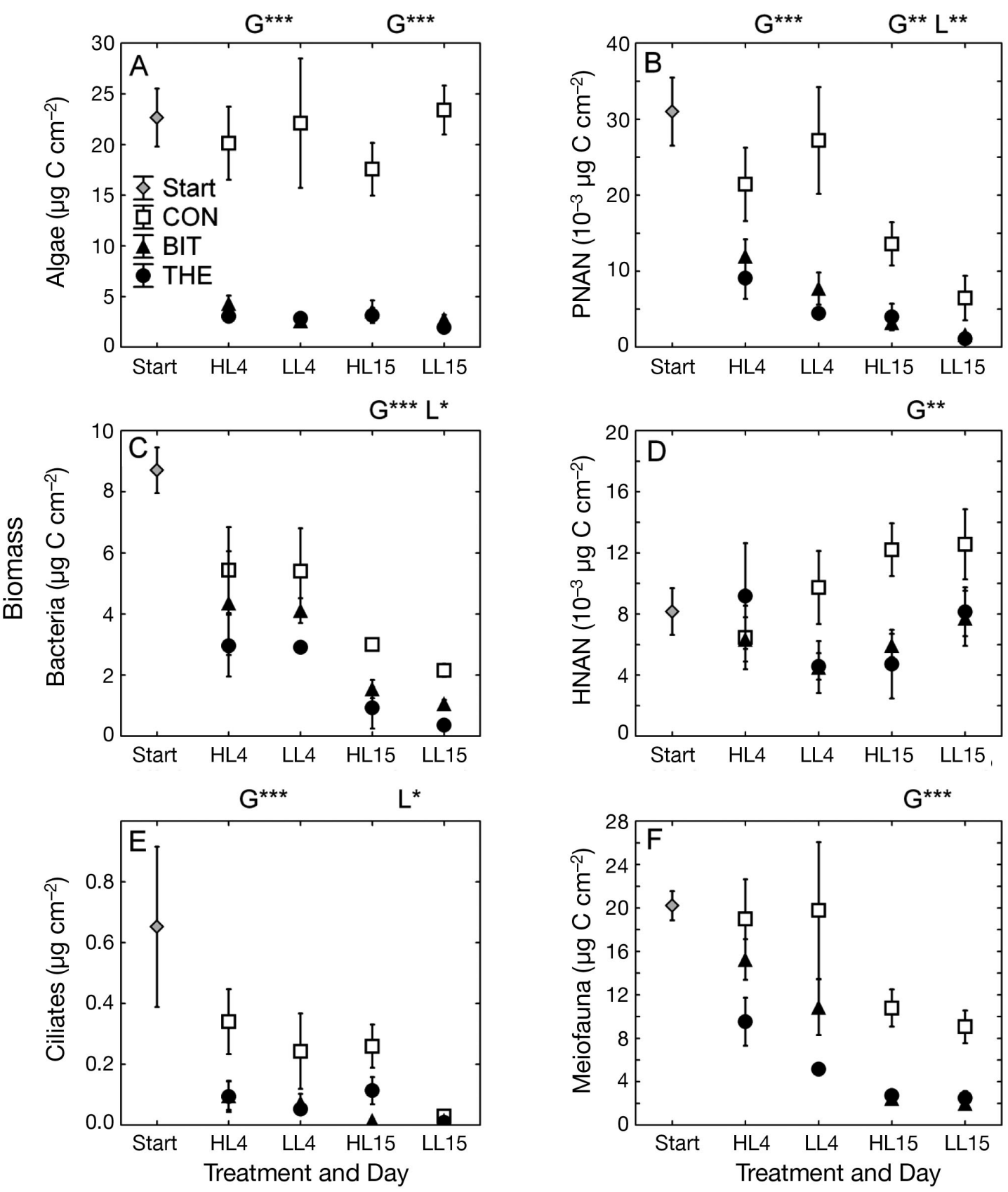

Fig. 3. Biomass of functional groups in Expt 2 at start, Day 4 and 15 for high (HL) and low (LL) light, for CON, BIT, and THE treatments. Error bars: $\pm 1 \mathrm{SE}$ of mean. All biomasses were converted to carbon units, but note different scales for the different panels (see especially the smaller units in B and D). (A) Algae. (B) PNAN. (C) Bacteria. (D) HNAN. (E) Ciliates. (F) Meiofauna. For factors with significant overall effects (repeated-measures ANOVA, see Table 1), the significant light (L) and grazing (G) effects for analyses on single sampling days are highlighted above each panel for Days 4 and 15 , respectively: ${ }^{* * *} \mathrm{p}<0.001,{ }^{* *} \mathrm{p}<0.01$,

${ }^{*} \mathrm{p}<0.05$. See Table 1 and Fig. 1 for definitions

grazing (Table 1), which was mainly related to presence of Bithynia tentaculata (CON = THE > BIT). Final biomass in BIT was 5.5 (HL) or $52.6 \%$ (LL) of CON biomass at the end of the experiment. Ciliate taxonomic composition on Day 15 was not affected by grazing, but by light (MANOVA, Pillai's Trace $=0.36, F_{2 ; 16}=$ $3.15, \mathrm{p}=0.038$ ), with Oligohymenophorea contributing more biomass at HL at the expense of the 'Other' ciliate group (Fig. 4D).

A significant light effect and time $\times$ light interaction were reflected by higher ciliate biomass at HL on Day 15 (Fig. 3E). Further examination of this light effect showed that the increase in ciliate biomass was purely dependent on 2 abundant species of mixo- 

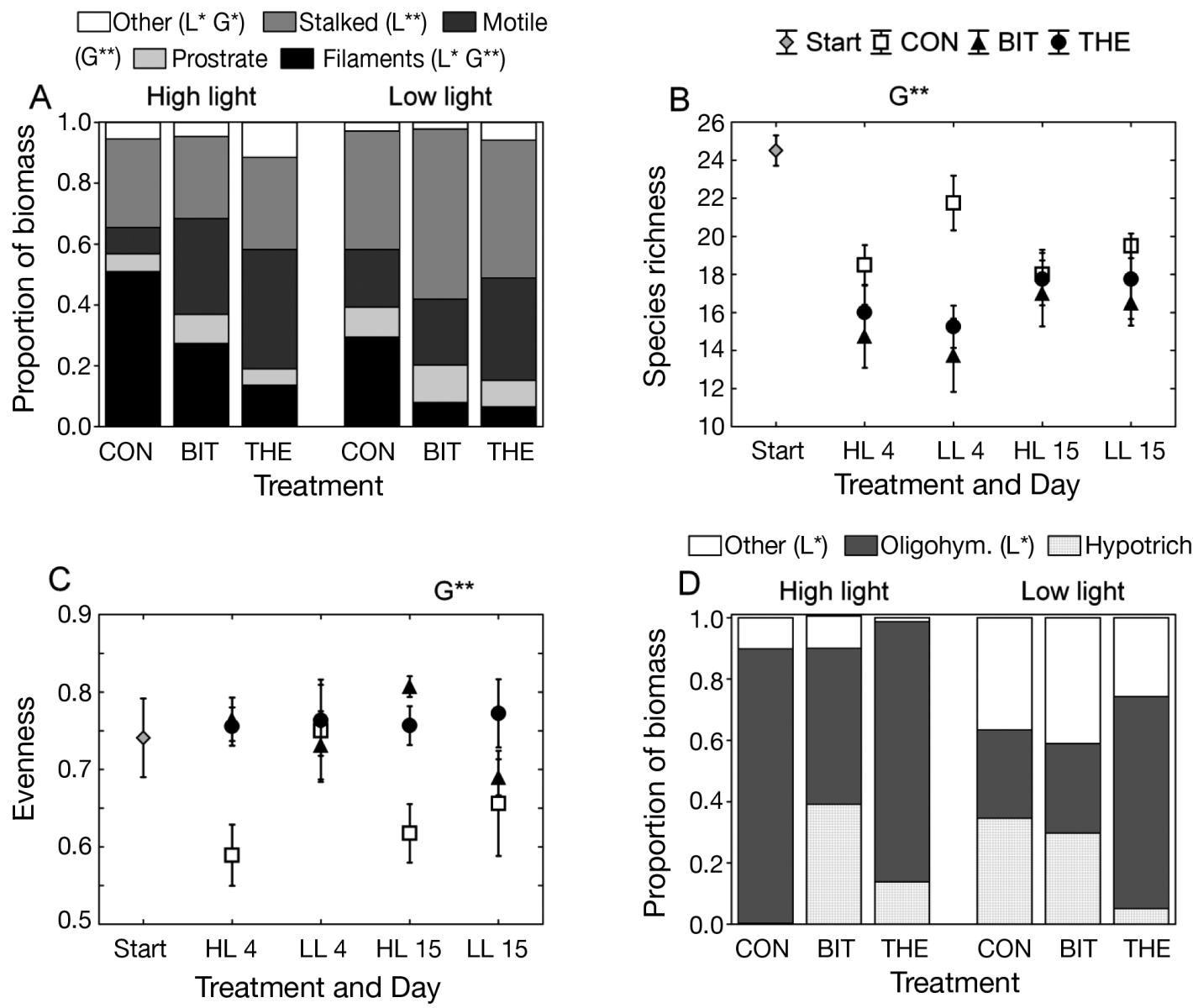

Fig. 4. Species composition and diversity for (A-C) algae and (D) ciliates in Expt 2. Error bars: \pm 1 SE of mean. (A) Final biomass proportion for different growth forms of microalgae. (B) Species richness and (C) evenness of algae in high (HL) and low (LL) light treatments at start, Day 4 and 15. (D) Final biomass proportion for 3 ciliates groups (Oligohymenophorea [Oligohym.], Hypotrichia and Stichotrichia [Hypotrich], Other). (A,D) For treatments with significant overall effects on algal or ciliate group composition (MANOVA), the significant grazing $(\mathrm{G})$ and light (L) effects on single algal groups are indicated in the key. (B, C) For factors with significant overall effects (repeated-measures ANOVA, see Table 1), the significant light and grazing effects for analyses on single sampling days are highlighted above each panel for Days 4 and 15 , respectively. ${ }^{* *} p<0.01$, ${ }^{*} p<0.05$.

Treatments: see Fig. 1 for definitions

trophic ciliates, Paramecium bursaria and a peritrich ciliate of the order Mobilida. Redoing the analysis for mixotroph biomass alone, the significance of grazer effects did not change, but the light effect was highly significant (rmANOVA, $F_{1 ; 18}=20.31, \mathrm{p}<0.001$ ) and a significant light $\times$ grazing interaction $\left(\mathrm{rmANOVA}, F_{2 ; 18}\right.$ $=9.09, \mathrm{p}=0.002$ ) showed that the increase with light was mainly observed in CON, where mixotrophs contributed $94 \%$ of ciliate biomass at HL compared to $24 \%$ at LL. Non-mixotrophs were not affected significantly by light ( $\mathrm{rmANOVA}, F_{1 ; 18}=1.37, \mathrm{p}=0.257$ ).

Total meiofauna biomass was clearly dominated by nematodes (98\%) and decreased significantly over time in all treatments (Fig. 3F, Table 1). Both grazers reduced meiofaunal biomass significantly $(\mathrm{CON}>\mathrm{BIT}=$ THE) to 22.3 (BIT) and $26.5 \%$ (THE) of the biomass in the ungrazed controls (averaged across light levels). A significant time $\times$ grazing interaction showed that grazing affected meiofaunal biomass only on Day 15. Meiofaunal biomass was higher at HL than at LL.

\section{DISCUSSION}

Heterotrophs contributed significantly to the overall periphyton biomass in both experiments: $20 \%$ in the first and $57 \%$ in the second experiment. This corresponds well to previous findings from the same system (Hillebrand et al. 2002) and underscores the importance of acknowledging the role of heterotrophs in the periphyton.

Grazing had a profound effect on the biomass of all components of the periphyton and in both experiments, suggesting that both snails are strong general- 
ist consumers. However, the strength of biomass reduction and the temporal dynamics of grazing effects differed strongly between the groups (accepting the first hypothesis that heterotrophic components of the periphyton show a different magnitude and temporal sequence of response to grazer presence). We will detail the discussion on the different functional groups below. More often than not, the 2 snail grazers differed in the magnitude of their effect on the different groups, as sometimes only one of the grazers showed a significant effect (Bithynia tentaculata on HNAN in both experiments, Theodoxus fluviatilis on meiofauna in Expt 1) or as the effect sizes were significantly different (stronger reduction in autotrophic biomass in THE than BIT). Thus, the second hypothesis, that responses differ for 2 snail species with known differences in grazing efficiency, is to be accepted. In contrast to the strong effect of grazing, the manipulation of light supply in Expt 2 had much weaker effects. Although several autotrophic and heterotrophic groups did respond to light (see next section), there was not a change towards a more heterotrophic assemblage as heterotrophs contributed $44 \%$ of the biomass under HL, and $32 \%$ under LL conditions at the end of the experiment. Consequently, no alteration of grazing effects on biomass with light supply was observed (refuting the third hypothesis). A significant grazing $\times$ light interaction was found only for algal evenness (see below).

\section{Autotrophic biomass and microalgal species composition}

Grazers had a strong negative impact on the biomass of both autotrophic groups, microalgae and nanoautotrophs (PNAN) in both experiments. The reduction in biomass was significant from Day 4 onwards (>Day 8 for PNAN in Expt 1) and corresponded to a loss of biomass between 74 and $99 \%$. Grazer-periphyton interactions are characterized by generally very high biomass removal efficiencies. In a meta-analysis comprising different aquatic systems, grazers were found to remove on average $59 \%$ of periphyton biomass across 865 experiments (Hillebrand 2009), with higher values adhering to laboratory studies like this one and extremes going up to $99 \%$. Effects of the 2 snail species were comparable, but in Expt 1, Theodoxus fluviatilis had stronger effects on the microalgae than Bithynia tentaculata, reflecting the high grazing efficiency reported for the former species (Jacoby 1985, Råberg \& Kautsky 2008).

By amending the classical Utermöhl counting by a more detailed assessment of PNAN, we were able to discern an important part of the autotrophic biomass. PNAN contributed $15 \%$ of autotrophic biomass in
Expt 1, but $<1 \%$ in Expt 2 . Whereas PNAN and microalgae responded similar to grazing treatments, the response to light manipulation in Expt 2 differed strongly. Contrary to expectations, the microalgae did not respond significantly to light reduction. When analysing the effects of grazing and light on the C:N:P stoichiometry of the periphyton (Hillebrand et al. 2004), we found that even in the presence of low light supply, the periphyton was characterized by very high $\mathrm{C}: \mathrm{P}$ ratios, indicating strong $\mathrm{P}$-limitation. Thus, the algae in Expt 2 were unable to respond to higher light availability due to the absence of available phosphorus. Only the small PNAN were able to double their biomass in the HL treatments, but from a very low absolute level of biomass. The only group profiting substantially from higher light supply were mixotrophic ciliates (see 'Ciliate biomass and species composition'), presumably because they were able to sequester $\mathrm{P}$ from ingested particles.

In Expt 1, the autotrophic biomass decreased in CON during the last $2 \mathrm{wk}$ of the experiment, which suggests that algae were also grazed by smaller fauna. In fact, the decline corresponds well to a very large increase in meiofaunal biomass and, less strongly, in ciliates (see Fig. 1E,F). Neither this increase in heterotrophs nor the decline in autotrophic biomass was observed in CON in Expt 2. Meiofauna consumption compensating for the absence of macrograzers has been observed before (Cattaneo \& Kalff 1986), but smaller consumers have often been considered less effective than snails (McCormick 1991). Still, protist or meiofaunal consumption may affect the biomass of algae, bacteria and smaller protozoa. Thus, the observed grazing effects on algae will not only comprise snail consumption, but also indirect effects mediated by changing trophic relationships within the periphyton (see below on meiofauna and protists).

Both grazers strongly changed microalgal community composition from the dominance of large filamentous and band-forming algae to small motile and prostrate forms. This shift in community architecture from dominance of large and erect life forms to the dominance of prostrate forms and single-celled species has been described regularly (Steinman et al. 1992, Steinman 1996, Hillebrand et al. 2000). Despite their similar feeding morphology, however, the 2 snails showed significant differences in their effects on growth forms. Only Theodoxus fluviatilis increased the relative proportion of unicellular motile diatoms, whereas Bithynia tentaculata's presence was associated with higher contribution of prostrate forms.

Microalgal diversity showed a significant response to treatments only in Expt 2, with a strong divergence between evenness and richness. Grazing reduced species richness but increased evenness in the algal 
assemblage, which matches a more general trend presented in a recent conceptual model (Hillebrand et al. 2007). This model suggests that grazers maintain high evenness by preventing the dominance of few species, whereas they reduce species richness by deleting rare species from the assemblage. The grazer effect on evenness became more positive in the presence of high light supply, adding to the evidence that consumermediated maintenance of prey diversity occurs predominantly at high resource supply (Proulx \& Mazumder 1998, Worm et al. 2002, Hillebrand et al. 2007).

\section{Bacteria}

Starting biomass of bacteria in Expt 1 was 3 times higher in BIT than in either CON or THE: a difference associated with high variance and not longer detectable after $2 \mathrm{~d}$. Whereas we are unable to detect the reason for this difference in starting conditions, we are highly confident that it did not affect further results on bacteria with regard to grazing or temporal development.

The reduction of bacterial biomass in the presence of grazers was significant from Day 2 onwards, and grazer presence led to reductions in bacterial biomass comparable to the autotrophs (48 to $97 \%$ removal). In contrast to an earlier field study in Lake Erken, we neither found an increase in bacterial biomass with grazing (Hillebrand et al. 2002) nor only weak effects as reported elsewhere (Mulholland et al. 1991, Liess \& Haglund 2007). Others have suggested that bacteria are assimilated less efficiently than algae (Morales \& Ward 2000). The significant reduction of bacterial biomass in our study might thus indicate a high efficiency of the 2 species employed here, especially of Theodoxus fluviatilis, which consistently showed a stronger effect on bacteria than Bithynia tentaculata. Alternatively, bacterial biomass might strongly decrease with reduced algal biomass. In fact, bacterial biomass was correlated strongly and positively to algal biomass from Day 4 onwards (Pearson correlation across treatments for each sampling date; Expt 1: r $>0.82, \mathrm{p}<$ $0.001, \mathrm{~N}=12$; Expt 2: $\mathrm{r}>0.61, \mathrm{p}<0.001, \mathrm{~N}=24$ ), i.e. as soon as grazer effects on algal biomass became significant. Moreover, bacteria showed a similar positive response to light as PNAN. Such positive correlations have been reported frequently as bacteria can rely on algal carbon exudates for their growth (Hepinstall \& Fuller 1994, Rier \& Stevenson 2001, Carr et al. 2005); however, they are not ubiquitous (Haglund \& Hillebrand 2005). Additionally, greater algal biomass provides a larger surface area for bacteria to colonize, and as bacteria are often physically associated with the algae, co-consumption by a macrograzer is inevitable.
In the ungrazed CON of Expt 1, bacterial biomass showed an initial increase that was followed by conspicuous peaks in the biomass of HNAN and ciliates. Whereas our measurements do not allow disentangling the presence of feeding relationships between the protists and bacteria, the temporal sequence of responses strongly suggests a bottom-up propagating effect on protist consumers. The absence of a bacterial peak in Expt 2 coincided then with the absence of increasing protist biomass in CON.

\section{Heterotrophic nanoflagellates}

The biomass of HNAN was very small in both experiments and reduced by grazing only at the end of the experiments in the presence of Bithynia tentaculata (the reduction by Theodoxus fluviatilis was similar but more variable). Flagellates have rarely if ever been quantified in experiments involving grazing on periphyton, such that there is no a priori knowledge on grazing efficiency on flagellates. Flagellates were also not assessed in the field study (Hillebrand et al. 2002) underlying the hypotheses of the laboratory experiments reported here. We have thus no means to discriminate between different hypotheses explaining the late and weak response of HNAN to grazing or why $B$. tentaculata removed HNAN biomass more reliably.

In the ungrazed CON, HNAN biomass showed a conspicuous peak on Day 4, with a sharp decline thereafter. As described above, this potentially reflects a response to the increase in bacterial biomass in CON. HNAN are consumers of bacteria in pelagic systems (Berninger et al. 1991), but in benthic systems, flagellate grazing of bacteria might be restricted by particleassociation and colony formation of the bacteria (Matz \& Kjelleberg 2005, Weitere et al. 2005). Our sampling destroyed colonies and clumps, which precludes detailing the proportion of free bacteria. The decline in HNAN biomass on Day 8 corresponds to a peak in ciliate biomass (see below), adding evidence to the notion that ciliates are effective consumers of flagellates in sediments (Epstein et al. 1992) and the pelagial (Berninger et al. 1991).

\section{Ciliate biomass and species composition}

Overall ciliate biomass showed a significant reduction by grazing only from Day 8 onwards in Expt 1, but already on Day 4 in Expt 2. In both experiments, Bithynia tentaculata was more efficient in biomass removal than Theodoxus fluviatilis, especially under HL conditions in Expt 2 (maximum removal $>94 \%$ ). However, even in grazed treatments in Expt 1, ciliate biomass 
increased initially, suggesting that consumption by macrograzers and response to the availability of bacterial and flagellate biomass resulted in an interactive bottom-up/top-down control of ciliate biomass. The strength of such bottom-up propagating effects was also evoked to explain the increase of ciliate biomass with macrozoobenthos presence in Lake Erken (Wickham et al. 2004). However, in the closed setting of the laboratory experiments, grazing pressure might override potential positive effects on ciliate biomass.

Ciliate group composition added evidence that ciliate biomass was not only responding to consumption by snails. The 2 dominant groups of ciliates found in the experiments were the Oligohymenophorea, which feed on nano-sized particles such as bacteria and small algae, and the hypo- and stichotrichs, which feed mainly on small and middle sized algae and were often found filled with diatoms of different sizes in the QPS preparations. The latter group declined in correlation with the decline in the biomass of algae that were edible for them, such that it was reduced by grazer presence and decreased at the end in CON. Oligohymenophorea are predators on bacteria and PNAN and showed constant biomass within the first $4 \mathrm{~d}$, but decreased afterwards in relation to bacterial and PNAN biomass.

The increasing ciliate biomass with light in Expt 2 was solely due to increasing abundance of 2 mixotrophic species, suggesting it to be a rather direct response to light availability than an indirect effect via trophic interactions. The availability of an alternative P-source for mixotrophs through ingestion of bacteria can explain why mixotrophic ciliates but not microalgae responded to the enhanced light supply. Previous analyses of the stoichiometry of resources in this system suggested an extremely strong P-limitation in Expt 2, indicated by high C:P ratios in the periphyton and undetectable dissolved P-concentrations (Hillebrand et al. 2004). Whereas microalgae were limited by the lack of dissolved $\mathrm{P}$, the mixotophs can derive $\mathrm{P}$ from ingested particles. In pelagic systems, mixotrophs are successful competitors of specialized phototrophs if they compensate elemental deficiency by heterotrophic nutrition (Nygaard \& Tobiesen 1993, Katechakis et al. 2005). A potential role of mixotrophs in periphyton has to our knowledge not been investigated, as the information on benthic mixotrophs generally is scarce (Moorthi \& Berninger 2006).

\section{Meiofauna}

As for heterotrophic protists, meiofauna responded later to grazer presence than the autotrophs. In Expt 1, this response was restricted to THE (>90\% removal), whereras meiofaunal biomass first increased and then weakly declined in BIT. In Expt 2, removal was $75 \%$ across treatments. Meiofaunal biomass in CON treatments increased in Expt 1, and stayed at rather high levels in Expt 2. The lower grazing effect of Bithynia tentaculata might reflect the high mobility of meiofauna compared to bacteria and protists.

In the absence of macrofauna, nematodes as the main component of the meiofauna were able to profit from the availability of food. The rise of meiofaunal biomass in Expt 1 corresponds to a decline of ciliate and algal biomass suggesting a strong top-down effect of meiofauna. Depending on feeding types and specialized mouthparts, the dietary preferences of nematodes include bacteria, diatoms and other algae (Bott 1996). In a series of laboratory experiments, Fitter \& Hillebrand (2009) found that the presence of meiofauna (rotifers in that case) exerted strong top-down effects in benthic microbial food webs and played a decisive role in the propagation of resource enrichment effects as well as the overall nutrient stoichiometry of the periphyton.

A recent survey of periphyton in lakes suggested that epilithon-associated meiofauna is abundant $\left(\sim 100\right.$ ind $\left.\mathrm{cm}^{-2}\right)$ and diverse $(\sim 15$ species comprising many different feeding types) (Peters \& Traunspurger 2005). Thus, meiofauna represents an important link between macro- and microscopic food webs in the benthos. In the absence of macroconsumers, meiofauna may trigger a substantial trophic cascade on the microalgae and protists in the benthic microbial food web. Meiofauna can partly compensate for the absence of larger grazers by exerting feeding pressure on algae, whereby different feeding modes relate to different efficiency and selectivity (Cattaneo \& Kalff 1986, Bott 1996, Bott \& Borchardt 1999). On the other hand, meiofauna is consumed by macrograzers (Peters et al. 2007), albeit our study indicates that meiofaunal biomass is reduced only in the face of highly efficient overall biomass removal such as by Theodoxus fluviatilis. Meiofauna thus represents an important aspect of food web complexity in benthic habitats (SchmidAraya \& Schmid 2000, Schmid-Araya et al. 2002).

\section{CONCLUSIONS}

Grazing by 2 generalist macroconsumers affected all components in periphyton, but did so with highly diverging efficiency and temporal sequence. Our study thus adds to the evidence that microbial interactions within the periphyton affect the composition and functioning of these assemblages (Bott 1996, Fitter \& Hillebrand 2009). Given the importance of periphyton for benthic (Lamberti 1996) and pelagic (Vadebon- 
coeur et al. 2002) food webs, it seems mandatory to disentangle the role of this internal microbial food web for the response of aquatic systems to altered nutrient supply, or consumer removal or addition. The use of stable isotopes and tracer additions might unravel some of the pathways we could not directly observe. A crucial step for a more realistic understanding of processes within the periphyton is the establishment of refined methods for separation of the functional groups in the samples in order to warrant separate analyses.

Two additional aspects of our results might be fruitful starts for further research: the importance of mixotrophs and the analysis of diversity. Whereas the role of mixotrophs in pelagic food webs is well analyzed, we know little about benthic mixotrophy, and even less on the role of mixotrophs in periphyton communities. Second, periphyton has been established as a model system to understand consumer-resource interactions and their effect on diversity (Sommer 2000, Hillebrand 2003, Cardinale et al. 2006). However, as in most studies, the analysis of diversity was restricted to the algae in this study. Periphyton is a candidate model system to test whether the functioning of entire assemblages depends on the diversity of all groups involved. As the debate on biodiversity effects on ecosystem functions moves forward to a more holistic view of multifunctionality (Gamfeldt et al. 2008), the close spatial arrangement and interdependency of functional groups in periphyton appears as a suitable system to test these aspects across trophic levels.

Acknowledgements. The research was funded by a Marie Curie Individual fellowship to H.H. (MCFI-2000-00912). We thank G. de Montpellier for her cooperation during the experiment and the Erken Laboratory, especially Prof. K. Pettersson, for providing facilities and help with measurements. Comments from R. Limberger improved the manuscript. The final analysis of these data has been done with financial aid through DFG grant Hi848/4-1 and 4-2.

\section{LITERATURE CITED}

Andrassy I (1956) Die Rauminhalts- und Gewichtsbestimmung der Fadenwürmer (Nematoden). Acta Zool Hung $2: 1-15$

- Arndt H (1993) Rotifers as predators on components of the microbial web (bacteria, heterotrophic flagellates, ciliates): a review. Hydrobiologia 255/256:231-246

Azam F, Fenchel T, Field JG, Gray JS, Meyer Reil LA, Thingstad F (1983) The ecological role of water-column microbes in the sea. Mar Ecol Prog Ser 10:257-263

Balushkina YV (1982) Body weight of chironomid larvae as a function of length. Hydrobiol J 18:53-60

Bell SS (1980) Meiofauna-macrofauna interactions in a high salt marsh habitat. Ecol Monogr 50:487-505

Berninger UG, Finlay BJ, Kuuppo Leinikki P (1991) Protozoan control of bacterial abundances in freshwater. Limnol Oceanogr 36:139-147
Borsheim KY, Bratbak G (1987) Cell volume to cell carbon conversion factors for a bacterivorous Monas spec. enriched from seawater. Mar Ecol Prog Ser 36:171-175

Bott TL (1996) Algae in microscopic food webs. In: Stevenson RJ, Bothwell ML, Lowe RL (eds) Algal ecology: freshwater benthic ecosystems. Academic Press, San Diego, CA, p 573-608

Bott TL, Borchardt MA (1999) Grazing of protozoa, bacteria, and diatoms by meiofauna in lotic epibenthic communities. J N Am Benthol Soc 18:499-513

> Brendelberger H (1997) Bacteria and digestive enzymes in the alimentary tract of Radix peregra (Gastropoda, Lymnaeidae). Limnol Oceanogr 42:1635-1638

> Brendelberger H, Jürgens S (1993) Suspension feeding in Bithynia tentaculata (Prosobranchia, Bithyniidae) as affected by body size, food and temperature. Oecologia 94: $36-42$

Cardinale BJ, Hillebrand H, Charles DF (2006) Geographic patterns of diversity in streams are predicted by a multivariate model of disturbance and productivity. J Ecol 94: 609-618

Carr GM, Morin A, Chambers PA (2005) Bacteria and algae in stream periphyton along a nutrient gradient. Freshw Biol 50:1337-1350

> Cattaneo A, Kalff J (1986) The effect of grazer size manipulation on periphyton communities. Oecologia 69:612-617

> Epstein SS, Gallagher ED (1992) Evidence for facilitation and inhibition of ciliate population growth by meiofauna and macrofauna on a temperate zone sandflat. J Exp Mar Biol Ecol 155:27-39

Epstein SS, Burkovsky IV, Shiaris MP (1992) Ciliate grazing on bacteria, flagellates, and microalgae in a temperate zone sandy tidal flat: ingestion rates and food niche partitioning. J Exp Mar Biol Ecol 165:103-123

Feller RJ, Warwick RM (1988) Energetics. In: Higgins RP, Thiel $\mathrm{H}$ (eds.) Introduction to the study of meiofauna. Smithsonian Institute Press, Washington, DC, p 181-196

$>$ Feminella JW, Hawkins CP (1995) Interactions between stream herbivores and periphyton: a quantitative analysis of past experiments. J N Am Benthol Soc 14:465-509

> Fenchel T (1982) Ecology of heterotrophic microflagellates. 4. Quantitative occurrence and importance as bacterial consumers. Mar Ecol Prog Ser 9:35-42

Fitter A, Hillebrand H (2009) Microbial food web structure affects bottom-up effects and elemental stoichiometry in periphyton assemblages. Limnol Oceanogr 54: 2183-2200

> Gamfeldt L, Hillebrand H, Jonsson PR (2008) Multiple functions increase the importance of biodiversity for overall ecosystem functioning. Ecology 89:1223-1231

Haglund AL, Hillebrand H (2005) The effect of grazing and nutrient supply on periphyton associated bacteria. FEMS Microbiol Ecol 52:31-41

> Hamels I, Moens T, Mutylaert K, Vyverman W (2001) Trophic interactions between ciliates and nematodes from an intertidal flat. Aquat Microb Ecol 26:61-72

Hepinstall JA, Fuller RL (1994) Periphyton reactions to different light and nutrient levels and the response of bacteria to these manipulations. Arch Hydrobiol 131:161-173

Hill WR (1996) Effects of light. In: Stevenson RJ, Bothwell ML, Lowe RL (eds) Algal ecology: freshwater benthic ecosystems. Academic Press, San Diego, CA, p 121-148

Hillebrand $\mathrm{H}$ (2003) Opposing effects of grazing and nutrients on diversity. Oikos 100:592-600

Hillebrand H, Gruner DS, Borer ET, Bracken MES and others (2007) Consumer versus resource control of producer diversity depends on ecosystem type and producer 
community structure. Proc Natl Acad Sci USA 104: 10904-10909

Hillebrand H (2009) Meta-analysis of grazer control of periphyton biomass across aquatic ecosystems. J Phycol 45: 798-806

Hillebrand H, Kahlert M (2001) Effect of grazing and nutrient supply on periphyton biomass and nutrient stoichiometry in habitats of different productivity. Limnol Oceanogr 46: 1881-1898

Hillebrand H, Sommer U (2000) Diversity of benthic microalgae in response to colonization time and eutrophication. Aquat Bot 67:221-236

Hillebrand H, Duerselen CD, Kirschtel DB, Pollingher U, Zohary $\mathrm{T}$ (1999) Biovolume calculation for pelagic and benthic microalgae. J Phycol 35:403-424

> Hillebrand H, Worm B, Lotze HK (2000) Marine microbenthic community structure regulated by nitrogen loading and grazing pressure. Mar Ecol Prog Ser 204:27-38

Hillebrand H, Kahlert M, Haglund AL, Berninger UG, Nagel S, Wickham S (2002) Control of microbenthic communities by grazing and nutrient supply. Ecology 83:2205-2219

Hillebrand H, de Montpellier G, Liess A (2004) Effects of macrograzers and light on periphyton stoichiometry. Oikos 106:93-104

Jacoby JM (1985) Grazing effects on periphyton by Theodoxus fluviatilis (Gastropoda) in a Lowland stream. J Freshwat Ecol 3:265-274

> Jürgens K, Skibbe O, Jeppesen E (1999) Impact of metazooplankton on the composition and population dynamics of planktonic ciliates in a shallow, hypertrophic lake. Aquat Microb Ecol 17:61-75

Katechakis A, Haseneder T, Kling R, Stibor H (2005) Mixotrophic versus photoautotrophic specialist algae as food for zooplankton: the light: nutrient hypothesis might not hold for mixotrophs. Limnol Oceanogr 50: 1290-1299

Lamberti GA (1996) The role of periphyton in benthic food webs. In: Stevenson RJ, Bothwell ML, Lowe RL (eds) Algal ecology: freshwater benthic ecosystems. Academic Press, San Diego, CA, p 533-572

> Lamberti GA, Resh VH (1983) Stream periphyton and insect herbivores: an experimental study of grazing by a caddisfly population. Ecology 64:1124-1135

Liess A, Haglund AL (2007) Periphyton responds differentially to nutrients recycled in dissolved or faecal pellet form by the snail grazer Theodoxus fluviatilis. Freshw Biol 52:1997-2008

> Loferer-Krößbacher M, Klima J, Psenner R (1998) Determination of bacterial cell dry mass by transmission electron microscopy and densitometric image analysis. Appl Environ Microbiol 64:688-694

Matz C, Kjelleberg S (2005) Off the hook: how bacteria survive protozoan grazing. Trends Microbiol 13:302-307

McCormick PV (1991) Lotic protistan herbivore selectivity and its potential impact on benthic algal assemblages. J N Am Benthol Soc 10:238-250

McManus GB, Fuhrman JA (1986) Bacterivory in seawater studied with the use of inert fluorescent particles. Limnol Oceanogr 31:420-426

Menden-Deuer S, Lessard EJ (2000) Carbon to volume relationships for dinoflagellates, diatoms, and other protist plankton. Limnol Oceanogr 45:569-579

Moorthi S, Berninger UG (2006) Mixotrophic nanoflagellates in coastal sediments in the western Baltic Sea. Aquat Microb Ecol 45:79-87

> Morales JBT, Ward AK (2000) Differential incorporation of algae and bacteria by Elimia clara (Prosobanchia: Pleuro- ceridae): a study using dual-labeled periphyton. J N Am Benthol Soc 19:289-297

Mulholland PJ, Steinman AD, Palumbo AV, Elwood JW, Kirschtel DB (1991) Role of nutrient cycling and herbivory in regulating periphyton communities in laboratory streams. Ecology 72:966-982

Nygaard K, Tobiesen A (1993) Bacterivory in algae: a survival strategy during nutrient limitation. Limnol Oceanogr 38:273-279

Peters L, Traunspurger W (2005) Species distribution of freeliving nematodes and other meiofauna in littoral periphyton communities of lakes. Nematology 7:267-280

Peters L, Hillebrand H, Traunspurger W (2007) Spatial variation of grazer effects on epilithic meiofauna and algae. J N Am Benthol Soc 26:78-91

Porter KG, Sherr EB, Sherr BF, Pace M, Sanders RW (1985) Protozoa in planktonic food webs. J Protozool 32:409-415

> Proulx M, Mazumder A (1998) Reversal of grazing impact on plant species richness in nutrient-poor vs. nutrient-rich ecosystems. Ecology 79:2581-2592

> Putt M, Stoecker DK (1989) An experimentally determined carbon:volume ratio for marine 'oligotrichous' ciliates from estuarine and coastal waters. Limnol Oceanogr 34: 1097-1103

Råberg S, Kautsky L (2008) Grazer identity is crucial for facilitating growth of the perennial brown alga Fucus vesiculosus. Mar Ecol Prog Ser 361:111-118

Rieper M (1985) Some lower food web organisms in the nutrition of marine harpacticoid copepods - an experimental study. Helgol Meersunters 39:357-366

> Rier ST, Stevenson RJ (2001) Relation of environmental factors to density of epilithic lotic bacteria in 2 ecoregions. J N Am Benthol Soc 20:520-532

Sanders RW, Wickham SA (1993) Planktonic protozoa and metazoa: predation, food quality and population control. Mar Microb Food Webs 7:197-223

Scheiner SM (1993) MANOVA: multiple response variables and multispecies interactions. In: Scheiner SM, Gurevitch $\mathrm{J}$ (eds) Design and analysis of ecological experiments. Chapman \& Hall, New York, NY, p 94-112

Schmid-Araya JM, Schmid PE (2000) Trophic relationships: integrating meiofauna into a realistic benthic food web. Freshw Biol 44:149-163

Schmid-Araya JM, Hildrew AG, Robertson A, Schmid PE, Winterbottom J (2002) The importance of meiofauna in food webs: evidence from an acid stream. Ecology 83: 1271-1285

Skibbe O (1994) An improved quantitative protargol stain for ciliates and other planktonic protists. Arch Hydrobiol 130:339-347

Sommer U (2000) Benthic microalgal diversity enhanced by spatial heterogeneity of grazing. Oecologia 122: 284-287

Steinman AD (1996) Effects of grazers on benthic freshwater algae. In: Stevenson RJ, Bothwell ML, Lowe RL (eds) Algal ecology: freshwater benthic ecosystems. Academic Press, San Diego, CA, p 341-373

Steinman AD, Mulholland PJ, Hill WR (1992) Functional responses associated with growth forms in stream algae. J N Am Benthol Soc 11:229-243

Stendera S (2000) Grazer-periphyton interactions. MSc thesis, University of Cologne

Traunspurger W (1997) Bathymetric, seasonal and vertical distribution of feeding-types of nematodes in an oligotrophic lake. Vie Milieu 47:1-47

Utermöhl H (1958) Zur Vervollkommnung der quantitativen Phytoplankton-Methodik. Mitt Int Ver Limnol 9:1-38 
Vadeboncoeur Y, Vander Zanden MJ, Lodge DM (2002) Putting the lake back together: reintegrating benthic pathways into lake food web models. Bioscience 52:44-54

Weitere M, Bergfeld T, Rice SA, Matz C, Kjelleberg S (2005) Grazing resistance of Pseudomonas aeruginosa biofilms depends on type of protective mechanism, developmental stage and protozoan feeding mode. Environ Microbiol 7:1593-1601

- Wickham SA, Nagel S, Hillebrand H (2004) Control of epiben-

Editorial responsibility: Rudger de Wit, Montpellier, France thic ciliate communities by grazers and nutrients. Aquat Microb Ecol 35:153-162

Wieltschnig C, Kirschner AKT, Fischer UR, Velimirov B (2003) Top-down control of benthic heterotrophic nanoflagellates by oligochaetes and microcrustaceans in a littoral freshwater habitat. Freshw Biol 48:1840-1849

- Worm B, Lotze HK, Hillebrand H, Sommer U (2002) Consumer versus resource control of species diversity and ecosystem functioning. Nature 417:848-851

Submitted: May 3, 2010; Accepted: August 12, 2010

Proofs received from author(s): October 6, 2010 